\title{
The sensitive period for the morphological effects of monocular deprivation in two nuclei of the tectofugal pathway of zebra finches
}

\author{
Kathrin Herrmann* and Hans-Joachim Bischof \\ Universität Bielefeld, Fakultät für Biologie, Verhaltensphysiologie, Bielefeld (F.R.G.)
}

(Accepted 24 November 1987)

Key words: Bird; Neuron size; Plasticity; Deprivation; Visual system; Development

\begin{abstract}
Previous experiments with 2-deoxyglucose (2-DG) suggested the existence of a critical period for the effects of monocular deprivation in the nucleus rotundus of zebra finches. The present study concerns the time course of this sensitive period for the morphological effects of monocular deprivation in two areas of the tectofugal visual pathway of zebra finches, the nucleus rotundus of the thalamus and the telencephalic ectostriatum. Cell size and volume changes were measured in birds subjected to 40 days of unilateral eye closure starting at ages spaced regularly throughout the first 70 days of life. The results show that monocular deprivation markedly affects cell size in both areas if the treatment starts at one or 10 days posthatch. The differences between deprived and non-deprived neurons decline monotonically with increasing visual experience prior to deprivation. However, deprivation onset at day 40 again causes as severe effects as early monocular closure. Deprivation as from day 50 or later no longer leads to abnormalities. The measurements of the volume of the nucleus rotundus parallel the cell size measurements, with the exception that the second increase in sensitivity occurs with deprivation onset at day 50 instead of day 40 . These data indicate that the time course of the sensitive period for the effects of monocular deprivation may be double-peaked: the sensitivity for external stimuli declines from hatch until day 30 , but has another peak at 40-50 days of life. The definite end of the sensitive period, as determined with this method, can therefore be assumed to be at around day $50-60$.
\end{abstract}

\section{INTRODUCTION}

In recent years many publications have reported that drastic alterations of the behavioral and neuronal development by environmental manipulations are often restricted to a limited time in the early ontogeny of an animal, the so-called 'critical period' or 'sensitive phase'. Besides the well-known sensitive phases for imprinting $3,29,36,37$, song learning ${ }^{35,42}$ (Böhner unpublished) and acoustic localization ${ }^{39}$ a large body of literature has accumulated concentrating on critical periods in the development of visual functions $s^{4,12,21}$. Especially the sensitive periods for the effects of monocular deprivation in the cat (e.g. refs. $6,10,11,31,33,38,45,50,51)$ and - to a lesser degree - in the monkey ${ }^{5,14,18,58}$ have been studied intensely with various methods and with differing re- sults. For example, whereas the beginning of the sensitive period for visual deprivation in the cat has been determined by most researchers to be around the third postnatal week, there is disagreement concerning its end (compare refs. 11, 33, 45, 51, 57).

In zebra finches the anatomical effects of monocular deprivation in the nucleus rotundus and the ectostriatum, two areas of the tectofugal pathway in birds $^{24,26,27,49}$, resemble in some respects those established in the geniculocortical pathway of various mammals (e.g. refs. 20, 22, 56, 60), although these regions are non-homologous. This is remarkable, as earlier studies had claimed this tectofugal pathway to be mainly monocularly driven ${ }^{2,53}$. Recent electrophysiological $^{15}$ and anatomical ${ }^{47}$ evidence from our lab, however, suggest a high degree of interaction in both of these areas in the zebra finch, so that the ob-

\footnotetext{
* Present address: University of California, Department of Psychology, Los Angeles, CA 90024, U.S.A. Correspondence: K. Herrmann, University of California, Los Angeles, Department of Psychology, 1283 Franz Hall, Los Angeles, CA 90024 , U.S.A.
} 
served changes following monocular eye closure should also be a result of disturbed competitive interactions. In addition, the results of our monocular deprivation experiments can only be interpreted as a disturbance of competition between the inputs from both eyes ${ }^{24,26,27,49}$.

As previous experiments with 2-deoxyglucose (2DG) suggested the existence of a sensitive period for the effects of unilateral occlusion in zebra finches ${ }^{26}$, the aim of this study was to determine the exact time course of this sensitive period by measurements of cell size and volume changes in two areas of the zebra finch brain, the nucleus rotundus of the thalamus and the telencephalic ectostriatum.

Of the two most common methods for the determination of a sensitive period, reverse suture experiments at different ages and onset delay of the deprivation period, we chose the second one, i.e. a period of 40 days of monocular eye closure was imposed on zebra finches at different ages. The period of 40 days was chosen as previous experiments have shown that this period creates stable asymmetries in cell size in nucleus rotundus ${ }^{26}$, whereas longer deprivation time leads to a decrease of soma size differences in the ectostriatum ${ }^{27}$.

Due to the complete crossing of the optic nerve in birds, the hemisphere contralateral to the deprived eye is called 'deprived hemisphere', the side ipsilateral to the deprived eye is termed 'un-' or 'non-deprived hemisphere'. The asymmetry in cell size between both hemispheres was used as a measure for deprivation effects. We have previously published an abstract of these findings ${ }^{28}$.

\section{MATERIALS AND METHODS}

\section{Animals}

A total of 26 zebra finches (Taeniopygia guttata castanotis) of both sexes from the institute's stock were subjected to 40 days of unilateral eye closure starting at ages spaced regularly from birth until adulthood. Eye closure was accomplished by glueing dark plastic caps with Dow Corning medical adhesive over one of the eyes.

The birds were deprived at the age of 1 or $2(n=$ $4)^{*}, 10(n=1), 20(n=4), 30(n=3) 40(n=5), 50(n$

\footnotetext{
* Data of this age group were taken from previous studies ${ }^{26,27}$.
}

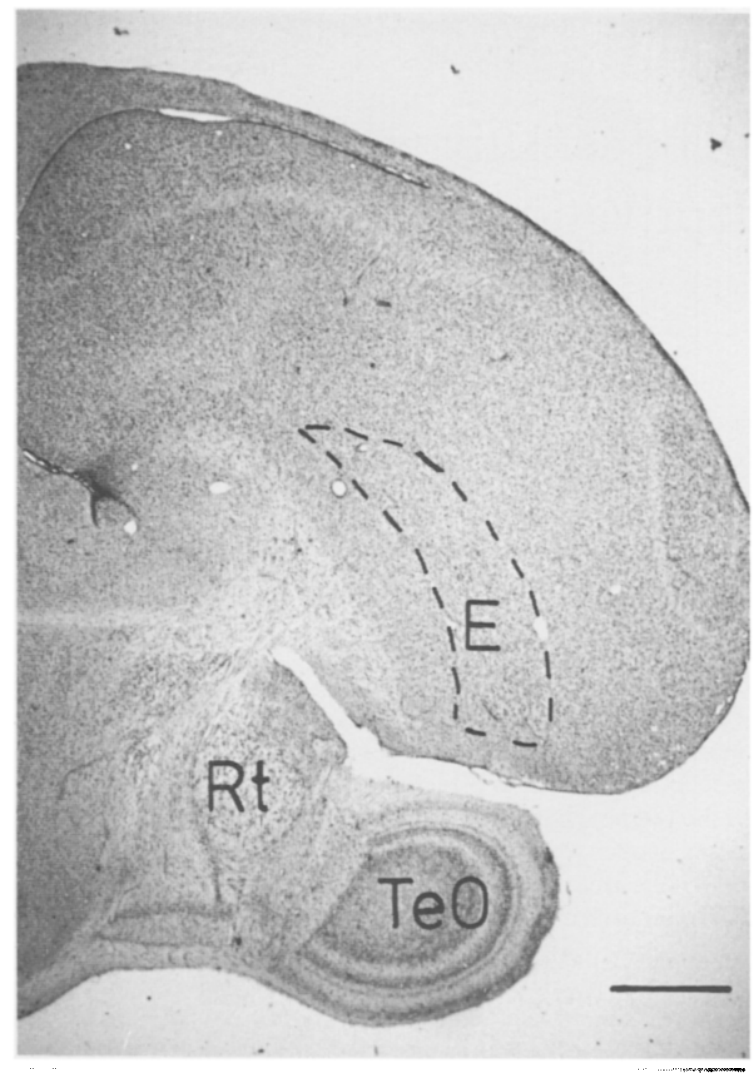

Fig. 1. Cross-section through a zebra finch brain, showing the main stations of the tectofugal pathway. E, ectostriatum; Rt, nucleus rotundus; TeO. tectum opticum. Bar $=1 \mathrm{~mm}$.

$=3), 60(n=3)$, and 70 days $(n=3)$. Immediately after the deprivation period of 40 days the birds were deeply anaesthetized with $0.03 \mathrm{ml} \mathrm{Nembutal}$ and perfused via the left ventricle with $0.9 \% \mathrm{NaCl}$, followed by $10 \%$ formaline in $0.9 \% \mathrm{NaCl}$. The brains were postfixed in formaline, removed from the skull and stored in a solution of $30 \%$ sucrose in $10 \%$ formaline overnight. Then they were cut into $30-\mu \mathrm{m}$-thick serial sections and every third section was mounted on gelatine-coated slides, counterstained with $1 \%$ Cresyl violet, dehydrated and coverslipped.

\section{Cell size}

For quantitative measurement of the cell size the outlines of 100 neurons with a visible nucleolus in the left and right nucleus rotundus and ectostriatum of each brain were drawn with a drawing tube attached to a Zeiss microscope. The microscopic magnification for the rotundus was $\times 800$, ectostriatal neurons were drawn under oil at a magnification of $\times 1250$. In 
order to compare identical regions in all animals, measurements were made in the medial section in rostrocaudal direction, and within this section only medial regions were selected. The cell size areas were calculated with the aid of a Hewlett Packard Graphics Tablet linked to an HP-Computer. The data were stored and size frequency histograms were plotted. The 100 cell size data of each brain were tested for left/right asymmetries (deprived vs non-deprived) with a two-tailed $t$-test and a $U$-test. Then the data of all brains of each age group were pooled according to hemisphere (deprived vs undeprived) and brain region (rotundus and ectostriatum). From these stored data the mean, median and standard deviation was calculated and the statistic comparison was performed by using a two-tailed $t$ - or $U$-test. As mean and median never differed by more than $2.5 \%$ and even the level of significance was identical, we only present the data of the $t$-test here. A significance level of $P<0.05$ was chosen as confidence coefficient. In total, the size of 8800 neurons were measured.

\section{Volume}

Due to the undefined boundary of the ectostriatum in Nissl preparations (see Fig. 1) the volume of this area could not be calculated with sufficient reproducibility. Therefore we only calculated the volume of the nucleus rotundus of the birds deprived at different ages. The cross-sectional surface of each nucleus rotundus in rostrocaudal direction was drawn at a magnification of $\times 79$ and measured with an HP Graphics tablet. These values were multiplied with $90 \mu \mathrm{m}$, (= intersection distance) and added up. For statistical comparison, again, the Students' $t$-test was used.

\section{RESULTS}

\section{Cell size}

The results of the cell size measurements, expressed as percent difference between deprived and non-deprived values, in the nucleus rotundus and in the ectostriatum of birds deprived at different ages are shown graphically in Figs. 2 and 4. Table I shows the individual results with means, S.D. and changes in percent.

Nucleus rotundus. Deprivation starting at one or two days posthatch results in a $15.6 \%$ asymmetry. Neurons in the deprived hemisphere exhibit a value of $175.09 \mu \mathrm{m}^{2}$. In the non-deprived hemisphere a value of $205.80 \mu \mathrm{m}^{2}$ was measured. The data show that monocular occlusion affects soma size in both visual areas, even if the deprivation onset is delayed. If zebra finches are deprived from day 10 until day 50 , neurons in the deprived rotundus are $9 \%$ smaller than neurons in the corresponding non-deprived eye $\left(t=2.586, P<0.0052,140.9 \mu \mathrm{m}^{2}\right.$ (dpr) vs $154.9 \mu \mathrm{m}^{2}$ (n-dpr).

In two of the birds deprived from day 20 until day 60 , rotundal neurons in the deprived hemisphere were significantly smaller than their undeprived counterparts. In two other birds of the same age group no size differences were found. The pooled data of these 4 birds reveal a significant asymmetry of $4 \%\left(174.5 \mu \mathrm{m}^{2}\right.$ vs $\left.181.8 \mu \mathrm{m}^{2}, t=1.9417, P<0.0027\right)$.

Neurons in the deprived rotundus of birds, deprived from day 30 to 70 , are $3.2 \%$ larger than the corresponding neurons in the contralateral hemisphere. The result, however, is statistically not significant $(t=1.3212, \mathrm{df}=594, P>0.08)$.

In contrast, deprivation onset at day 40 produces highly significant asymmetries in cell size: neurons contralateral to the deprived eye are significantly smaller by $13.6 \%$ than those ipsilateral to the deprived eye $\left(171.7 \mu \mathrm{m}^{2}\right.$ vs $199.0 \mu \mathrm{m}^{2}, t=6.7531, P<$ 0.0001 ). One brain (FL), however, did not show a significant left-right difference.

Monocular occlusion starting at 50,60 or 70 days of age does not seem to have measurable effects on the soma size in the nucleus rotundus: In all 9 birds deprived from day 50 (EE, EY, EZ, $t=0.5842, P>$ 0.25 ), day 60 (EN, EX, EU, $t=0.1618, P>0.4)$ and day 70 (EM, FM, TN, $t=0.0035, P>0.4$ ) the differences in soma size between deprived and non-deprived neurons, ranging from 0.4 to $3.6 \%$, are not significant in any case.

Ectostriatum. If zebra finches were deprived from birth until day 40 , the interhemispheric asymmetry in the ectostriatal neuron size was calculated to be $18.4 \%\left(73.33 \mu \mathrm{m}^{2}\right.$ (dpr) vs $89.88 \mu \mathrm{m}^{2}$ (n-dpr)).

In zebra finches deprived from day 10 until day 50 the mean soma size was $72.3 \mu \mathrm{m}^{2}$ in the deprived ectostriatum and $78.03 \mu \mathrm{m}^{2}$ in the non-deprived hemisphere. The difference of $7.4 \%$ is statistically significant $(t=2.57$, df $=198, P<0.0054)$. 
TABLE I

Soma size $\pm S . E$. in the nucleus rotundus (a) and the ectostriatum (b) of zebra finches deprived at different ages

$\mathrm{ZF}$, zebra finch; d/n-dpr (\%), percental difference between deprived and non-deprived neuron size.

\begin{tabular}{|c|c|c|c|c|}
\hline & \multirow[t]{2}{*}{$Z F$} & \multicolumn{2}{|l|}{ Soma size $\left(\mu m^{2}\right)$} & \multirow[b]{2}{*}{$d / n-d p r(\%)$} \\
\hline & & Deprived & Non-deprived & \\
\hline $\begin{array}{l}\text { a. Nucleus rotur } \\
\text { Day } 1-40\end{array}$ & $\begin{array}{l}\text { BW } \\
\text { AT } \\
\text { BK } \\
\text { Mean }\end{array}$ & $\begin{array}{l}149.12 \pm 46.42 \\
176.13 \pm 43.13 \\
200.01 \pm 62.47 \\
175.09 \pm 55.82\end{array}$ & $\begin{array}{l}183.78 \pm 43.80 \\
190.75 \pm 49.15 \\
242.87 \pm 65.87 \\
205.80 \pm 60.42\end{array}$ & $\begin{array}{l}-18.86^{* * *} \\
-7.66^{*} \\
-17.65^{* * *} \\
-14.92^{* * *}\end{array}$ \\
\hline Day $10-50$ & $\begin{array}{l}\text { EG } \\
\text { Mean }\end{array}$ & $\begin{array}{l}140.90 \pm 36.38 \\
140.90 \pm 36.38\end{array}$ & $\begin{array}{l}154.91 \pm 39.55 \\
154.91 \pm 39.55\end{array}$ & $\begin{array}{l}-9.04^{* *} \\
-9.04^{* *}\end{array}$ \\
\hline Day 20-60 & $\begin{array}{l}\text { CM } \\
\text { CO } \\
\text { CT } \\
\text { DG } \\
\text { Mean }\end{array}$ & $\begin{array}{l}155.81 \pm 37.88 \\
192.74 \pm 63.05 \\
181.54 \pm 54.69 \\
167.88 \pm 52.67 \\
174.49 \pm 54.45\end{array}$ & $\begin{array}{l}169.24 \pm 41.98 \\
192.36 \pm 73.43 \\
180.48 \pm 58.64 \\
184.92 \pm 61.09 \\
181.81 \pm 60.23\end{array}$ & $\begin{array}{l}-7.94^{* *} \\
+0.20 \text { n.s. } \\
+0.59 \text { n.s. } \\
-9.21^{* *} \\
-4.03^{*}\end{array}$ \\
\hline Day $30-70$ & $\begin{array}{l}\text { CI } \\
\text { CR } \\
\text { CU } \\
\text { Mean }\end{array}$ & $\begin{array}{l}193.77 \pm 48.83 \\
201.70 \pm 54.79 \\
192.35 \pm 54.59 \\
195.94 \pm 52.83\end{array}$ & $\begin{array}{l}180.29 \pm 47.97 \\
190.80 \pm 66.94 \\
198.07 \pm 62.20 \\
189.81 \pm 60.13\end{array}$ & $\begin{array}{l}+6.96^{*} \\
+5.41^{*} \\
-2.89 \text { n.s. } \\
+3.23 \text { n.s. }\end{array}$ \\
\hline Day $40-80$ & $\begin{array}{l}\text { CG } \\
\text { DX } \\
\text { EW } \\
\text { FL } \\
\text { FK } \\
\text { Mean }\end{array}$ & $\begin{array}{l}203.78 \pm 54.34 \\
184.54 \pm 59.27 \\
162.94 \pm 42.88 \\
144.76 \pm 57.14 \\
162.42 \pm 43.00 \\
171.69 \pm 55.52\end{array}$ & $\begin{array}{l}241.44 \pm 73.46 \\
206.29 \pm 62.86 \\
188.49 \pm 49.10 \\
151.21 \pm 55.82 \\
207.61 \pm 64.90 \\
199.01 \pm 67.53\end{array}$ & $\begin{array}{c}-15.60^{* * *} \\
-10.54^{* * *} \\
-13.56^{* * *} \\
-4.40 \mathrm{n.s} \\
-21.77^{* * *} \\
-13.59^{* * *}\end{array}$ \\
\hline Day $50-90$ & $\begin{array}{l}\text { EE } \\
\text { EY } \\
\text { EZ } \\
\text { Mean }\end{array}$ & $\begin{array}{l}157.43 \pm 43.07 \\
170.23 \pm 56.45 \\
214.39 \pm 65.80 \\
180.69 \pm 60.51\end{array}$ & $\begin{array}{l}158.13 \pm 45.01 \\
167.00 \pm 56.45 \\
208.43 \pm 73.45 \\
177.85 \pm 65.02\end{array}$ & $\begin{array}{l}-0.44 \text { n.s. } \\
+1.93 \text { n.s. } \\
+2.86 \text { n.s. } \\
+1.60 \text { n.s. }\end{array}$ \\
\hline Day $60-100$ & $\begin{array}{l}\text { EN } \\
\text { EX } \\
\text { EU } \\
\text { Mean }\end{array}$ & $\begin{array}{l}135.41 \pm 48.52 \\
159.02 \pm 44.30 \\
193.07 \pm 58.07 \\
162.50 \pm 56.70\end{array}$ & $\begin{array}{l}134.77 \pm 54.05 \\
161.85 \pm 38.72 \\
188.12 \pm 54.94 \\
161.58 \pm 52.96\end{array}$ & $\begin{array}{l}+0.47 \text { n.s. } \\
-1.75 \text { n.s. } \\
+2.63 \text { n.s. } \\
+0.57 \text { n.s. }\end{array}$ \\
\hline Day 70-110 & $\begin{array}{l}\text { EM } \\
\text { FN } \\
\text { FM } \\
\text { Mean }\end{array}$ & $\begin{array}{l}128.55 \pm 45.68 \\
156.03 \pm 44.26 \\
168.20 \pm 45.58 \\
150.93 \pm 48.10\end{array}$ & $\begin{array}{l}130.50 \pm 50.77 \\
159.56 \pm 46.93 \\
162.43 \pm 47.24 \\
150.83 \pm 50.20\end{array}$ & $\begin{array}{l}-1.49 \text { n.s. } \\
-2.21 \text { n.s. } \\
+3.55 \text { n.s. } \\
+0.07 \text { n.s. }\end{array}$ \\
\hline $\begin{array}{l}\text { b. Ectostriatum } \\
\text { Day } 1-40\end{array}$ & $\begin{array}{l}\text { BW } \\
\text { AT } \\
\text { BK } \\
\text { Mean }\end{array}$ & $\begin{array}{l}61.35 \pm 17.14 \\
76.84 \pm 16.00 \\
81.81 \pm 18.09 \\
73.33 \pm 19.16\end{array}$ & $\begin{array}{r}72.65 \pm 16.43 \\
84.33 \pm 20.26 \\
112.65 \pm 28.11 \\
89.88 \pm 27.27\end{array}$ & $\begin{array}{c}-15.55^{* * *} \\
-8.88^{* *} \\
-27.38^{* * *} \\
-18.41^{* * *}\end{array}$ \\
\hline Day $10-50$ & $\begin{array}{l}\text { EG } \\
\text { Mean }\end{array}$ & $\begin{array}{l}72.28 \pm 15.86 \\
72.28 \pm 15.86\end{array}$ & $\begin{array}{l}78.03 \pm 15.86 \\
78.03 \pm 15.86\end{array}$ & $\begin{array}{l}-7.37^{* *} \\
-7.37^{* *}\end{array}$ \\
\hline Day 20-60 & $\begin{array}{l}\mathrm{CM} \\
\mathrm{CO} \\
\mathrm{CT} \\
\mathrm{DG} \\
\text { Mean }\end{array}$ & $\begin{array}{l}62.65 \pm 15.00 \\
72.76 \pm 15.83 \\
78.64 \pm 15.80 \\
77.83 \pm 19.06 \\
72.97 \pm 17.08\end{array}$ & $\begin{array}{l}69.41 \pm 16.58 \\
82.32 \pm 19.03 \\
81.73 \pm 21.43 \\
87.39 \pm 22.25 \\
80.21 \pm 18.09\end{array}$ & $\begin{array}{c}-9.74^{* *} \\
-11.29^{* * *} \\
-3.78 \text { n.s. } \\
-10.94^{* * *} \\
-9.20^{* * *}\end{array}$ \\
\hline Day $30-70$ & $\begin{array}{l}\text { CI } \\
\text { CR } \\
\text { CU } \\
\text { Mean }\end{array}$ & $\begin{array}{l}72.53 \pm 14.37 \\
64.13 \pm 14.97 \\
86.81 \pm 19.32 \\
74.49 \pm 18.86\end{array}$ & $\begin{array}{l}65.35 \pm 14.95 \\
67.63 \pm 15.47 \\
81.90 \pm 18.93 \\
71.63 \pm 18.09\end{array}$ & $\begin{array}{c}+10.99^{* * *} \\
-5.17^{*} \\
+6.00^{*} \\
+3.99^{*}\end{array}$ \\
\hline
\end{tabular}


TABLE I (continued)

\begin{tabular}{|c|c|c|c|c|}
\hline & \multirow[t]{2}{*}{$Z F$} & \multicolumn{3}{|l|}{ Soma size $\left(\mu m^{2}\right)$} \\
\hline & & Deprived & Non-deprived & $d / n-d p r(\%)$ \\
\hline Day $40-80$ & $\begin{array}{l}\text { CG } \\
\text { DX } \\
\text { EW } \\
\text { FL } \\
\text { FK } \\
\text { Mean }\end{array}$ & $\begin{array}{l}65.30 \pm 13.55 \\
87.28 \pm 23.07 \\
65.30 \pm 20.82 \\
73.18 \pm 17.93 \\
70.69 \pm 15.62 \\
72.42 \pm 19.78\end{array}$ & $\begin{array}{r}75.07 \pm 15.63 \\
102.77 \pm 19.20 \\
93.71 \pm 30.72 \\
71.27 \pm 17.70 \\
92.45 \pm 27.80 \\
87.05 \pm 27.10\end{array}$ & $\begin{array}{l}-13.01^{* * *} \\
-15.07^{* * *} \\
-29.90^{* * *} \\
+2.68 \text { n.s. } \\
-23.56^{* * *} \\
-16.81^{* * *}\end{array}$ \\
\hline Day $50-90$ & $\begin{array}{l}\text { EE } \\
\text { EY } \\
\text { EZ } \\
\text { Mean }\end{array}$ & $\begin{array}{l}75.65 \pm 23.28 \\
67.68 \pm 16.77 \\
75.09 \pm 21.46 \\
72.81 \pm 20.60\end{array}$ & $\begin{array}{l}78.89 \pm 16.98 \\
69.04 \pm 15.36 \\
77.62 \pm 20.57 \\
75.18 \pm 18.90\end{array}$ & $\begin{array}{l}-4.11 \text { n.s. } \\
-1.97 \text { n.s. } \\
-3.25 \text { n.s. } \\
-3.15 \text { n.s. }\end{array}$ \\
\hline Day $60-100$ & $\begin{array}{l}\text { EN } \\
\text { EX } \\
\text { EU } \\
\text { Mean }\end{array}$ & $\begin{array}{l}72.71 \pm 15.53 \\
86.22 \pm 16.60 \\
57.73 \pm 12.35 \\
72.22 \pm 15.61\end{array}$ & $\begin{array}{l}73.08 \pm 16.93 \\
87.46 \pm 17.96 \\
58.09 \pm 15.59 \\
72.88 \pm 17.34\end{array}$ & $\begin{array}{l}-0.51 \mathrm{n} . \mathrm{s} . \\
-1.42 \mathrm{n} . \mathrm{s} . \\
-0.62 \mathrm{n} . \mathrm{s} . \\
-0.91 \mathrm{n} . \mathrm{s} .\end{array}$ \\
\hline Day $70-110$ & $\begin{array}{l}\text { EM } \\
\text { FN } \\
\text { FM } \\
\text { Mean }\end{array}$ & $\begin{array}{l}60.56 \pm 14.18 \\
76.51 \pm 16.13 \\
75.46 \pm 15.72 \\
70.84 \pm 16.93\end{array}$ & $\begin{array}{l}60.88 \pm 12.54 \\
79.10 \pm 17.99 \\
79.42 \pm 18.61 \\
73.13 \pm 18.65\end{array}$ & $\begin{array}{l}-0.53 \text { n.s. } \\
-3.37 \text { n.s. } \\
-4.99 \text { n.s. } \\
-3.13 \text { n.s. }\end{array}$ \\
\hline
\end{tabular}

${ }^{* * *} P<0.0001,{ }^{* *} P<0.001,{ }^{*} P<0.05$, n.s., not significant.

Monocular deprivation from day 20 to 60 also results in a significant left-right asymmetry: neurons in

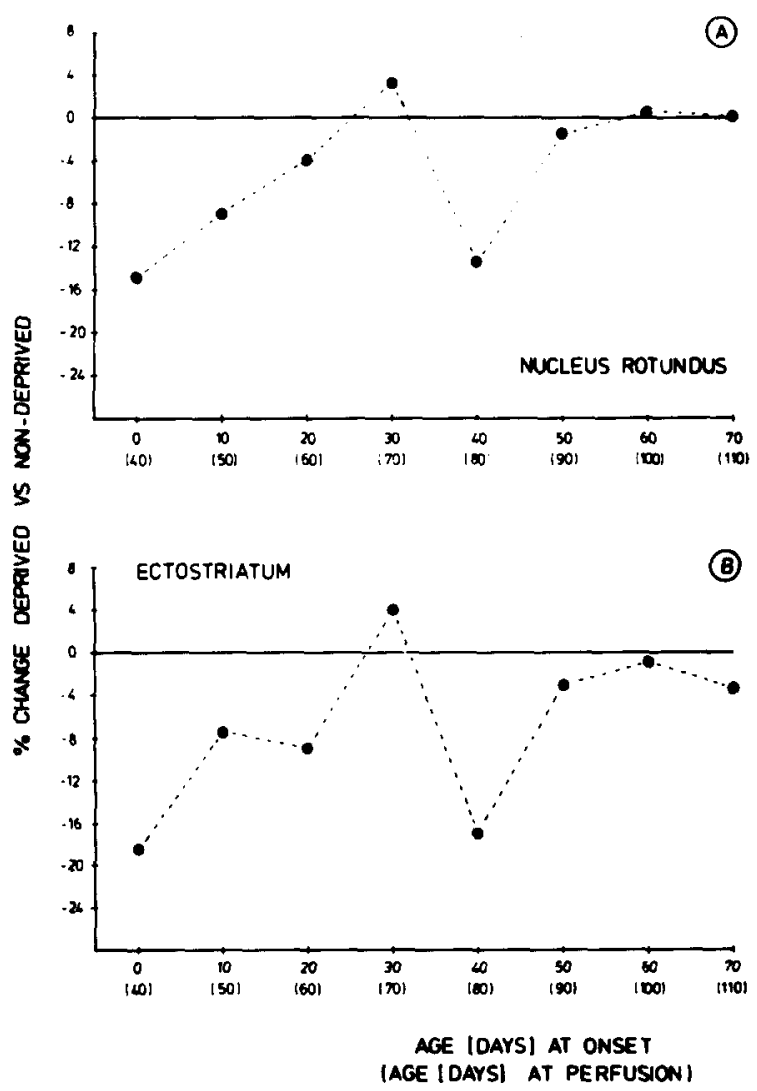

the deprived ectostriatum are significantly smaller $(t$ $=5.3732, P<0.0001)$ than those in the non-deprived hemisphere $\left(72.97 \mu \mathrm{m}^{2}\right.$ vs $\left.78.08 \mu \mathrm{m}^{2}\right)$. The difference is $9.2 \%$.

The results for cell size after monocular occlusion from day 30 until 70 are not very clear. In two of the brains neurons in the deprived ectostriatum are 6 and $11 \%$ larger (CU: $t=1.836, P<0.034, \mathrm{CI}: t=3.42, P$ $<0.0004)$ than the corresponding neurons in the non-deprived hemisphere, whereas the means of the soma size measurements of brain CR show the opposite result. Taken together, the result is a $4 \%$ hypertrophy of neurons in the deprived hemisphere (74.49 $\mu \mathrm{m}^{2}$ vs $71.63 \mu \mathrm{m}^{2}, t=1.8743, P<0.03$ ).

As in the nucleus rotundus, monocular deprivation from day 40 to 80 results in very drastic effects: there is a highly significant difference in the soma size between the deprived and the non-deprived hemisphere of $16.8 \%\left(72.81 \mu \mathrm{m}^{2}\right.$ vs $87.05 \mu \mathrm{m}^{2}, t=9.86, P$ $<0.0001)$.

Fig. 2. Effects of monocular deprivation on cell size in the nucleus rotundus (A) and ectostriatum (B) of zebra finches subjected to 40 days of monocular occlusion at various ages. The percental difference between the neuron size in the deprived and non-deprived hemisphere is plotted against the age at deprivation onset (the non-deprived hemisphere was set $100 \%$ ). A '-' indicates smaller neurons in the deprived hemisphere, a ' + ' stands for larger neurons in the deprived side. 
In zebra finches deprived from day 50 , neurons in the deprived ectostriatum are $3.15 \%$ smaller than those in the corresponding non-deprived hemisphere. The difference, however, is statistically not significant at the $95 \%$ level $\left(72.81 \mu \mathrm{m}^{2}\right.$ vs $75.18 \mu \mathrm{m}^{2}, t$ $=1.4031, P<0.081$ ).

Unilateral occlusion at day 60 or 70 again does not influence the size of neurons in this telencephalic area. The interhemispheric difference in birds deprived at day 60 is $0.91 \%\left(72.22 \mu \mathrm{m}^{2}\right.$ vs $\left.72.88 \mu \mathrm{m}^{2}\right)$, and for deprivation at day 70 an asymmetry of $3.13 \%$ was calculated $\left(70.84 \mu \mathrm{m}^{2}\right.$ vs $73.13 \mu \mathrm{m}^{2}, t=1.4814, P$ $>0.065$ ).

\section{Volume}

The results of the measurements of the volume of the nucleus rotundus in birds deprived at different ages are shown in Figs. 3 and 5 and Table II.

Monocular deprivation starting at birth results in a significant left-right asymmetry in the rotundus volume of $10.64 \%\left(0.403 \mathrm{~mm}^{3} \mathrm{vs} 0.451 \mathrm{~mm}^{3}\right)$.

In the bird deprived from day 10 until 50 the differ-

TABLE II

Rotundus volume of zebra finches deprived at different ages

ZF, zebra finch; $\mathrm{d} / \mathrm{n}-\mathrm{dpr}(\%)$, percental difference between the deprived and the non-deprived rotundus-volume.

\begin{tabular}{|c|c|c|c|c|}
\hline & \multirow[t]{2}{*}{$Z F$} & \multicolumn{3}{|l|}{ Volume $\left(\mathrm{mm}^{3}\right)$} \\
\hline & & Deprived & Non-deprived & $d / n-d p r(\%)$ \\
\hline Day $1-40$ & $\begin{array}{l}\text { BW } \\
\text { AT } \\
\text { BK } \\
\text { CC } \\
\text { Mean }\end{array}$ & $\begin{array}{l}0.350 \\
0.448 \\
0.375 \\
0.437 \\
0.403 \pm 0.048\end{array}$ & $\begin{array}{l}0.389 \\
0.481 \\
0.463 \\
0.472 \\
0.451 \pm 0.042\end{array}$ & $\begin{array}{r}-10.02 \\
-6.86 \\
-19.01 \\
-7.42 \\
-10.64\end{array}$ \\
\hline Day $10-50$ & $\begin{array}{l}\text { EG } \\
\text { Mean }\end{array}$ & $\begin{array}{l}0.370 \\
0.370\end{array}$ & $\begin{array}{l}0.418 \\
0.418\end{array}$ & $\begin{array}{l}-11.48 \\
-11.48\end{array}$ \\
\hline Day 20-60 & $\begin{array}{l}\text { CT } \\
\text { CO } \\
\text { CM } \\
\text { Mean }\end{array}$ & $\begin{array}{l}0.443 \\
0.371 \\
0.424 \\
0.413 \pm 0.037\end{array}$ & $\begin{array}{l}0.490 \\
0.401 \\
0.437 \\
0.443 \pm 0.045\end{array}$ & $\begin{array}{l}-9.59 \\
-7.48 \\
-2.97 \\
-6.68\end{array}$ \\
\hline Day $30-70$ & $\begin{array}{l}\text { CU } \\
\text { CR } \\
\text { CI } \\
\text { Mean }\end{array}$ & $\begin{array}{l}0.361 \\
0.364 \\
0.371 \\
0.365 \pm 0.005\end{array}$ & $\begin{array}{l}0.382 \\
0.398 \\
0.400 \\
0.393 \pm 0.010\end{array}$ & $\begin{array}{l}-5.50 \\
-8.54 \\
-7.25 \\
-7.12\end{array}$ \\
\hline Day $40-80$ & $\begin{array}{l}\text { CG } \\
\text { DX } \\
\text { EW } \\
\text { FL } \\
\text { FK } \\
\text { Mean }\end{array}$ & $\begin{array}{l}0.398 \\
0.397 \\
0.462 \\
0.536 \\
0.333 \\
0.425 \pm 0.077\end{array}$ & $\begin{array}{l}0.412 \\
0.427 \\
0.449 \\
0.536 \\
0.350 \\
0.435 \pm 0.067\end{array}$ & $\begin{array}{l}-3.40 \\
-7.03 \\
+2.90 \\
\pm 0 \\
-4.86 \\
-2.30\end{array}$ \\
\hline Day $50-90$ & $\begin{array}{l}\text { EE } \\
\text { EZ } \\
\text { EY } \\
\text { Mean }\end{array}$ & $\begin{array}{l}0.324 \\
0.490 \\
0.459 \\
0.424 \pm 0.088\end{array}$ & $\begin{array}{l}0.358 \\
0.486 \\
0.516 \\
0.453 \pm 0.084\end{array}$ & $\begin{array}{r}-9.50 \\
+0.82 \\
-11.04 \\
-6.40\end{array}$ \\
\hline Day $60-100$ & $\begin{array}{l}\text { EN } \\
\text { EX } \\
\text { EU } \\
\text { Mean }\end{array}$ & $\begin{array}{l}0.394 \\
0.351 \\
0.484 \\
0.410 \pm 0.068\end{array}$ & $\begin{array}{l}0.382 \\
0.353 \\
0.496 \\
0.410 \pm 0.062\end{array}$ & $\begin{array}{l}+3.14 \\
-0.57 \\
-2.42 \\
-0.13\end{array}$ \\
\hline Day $70-110$ & $\begin{array}{l}\text { EM } \\
\text { FM } \\
\text { FN } \\
\text { Mean }\end{array}$ & $\begin{array}{l}0.335 \\
0.429 \\
0.357 \\
0.374 \pm 0.049\end{array}$ & $\begin{array}{l}0.337 \\
0.428 \\
0.377 \\
0.381 \pm 0.046\end{array}$ & $\begin{array}{l}-0.59 \\
-0.23 \\
-5.70 \\
-1.84\end{array}$ \\
\hline
\end{tabular}




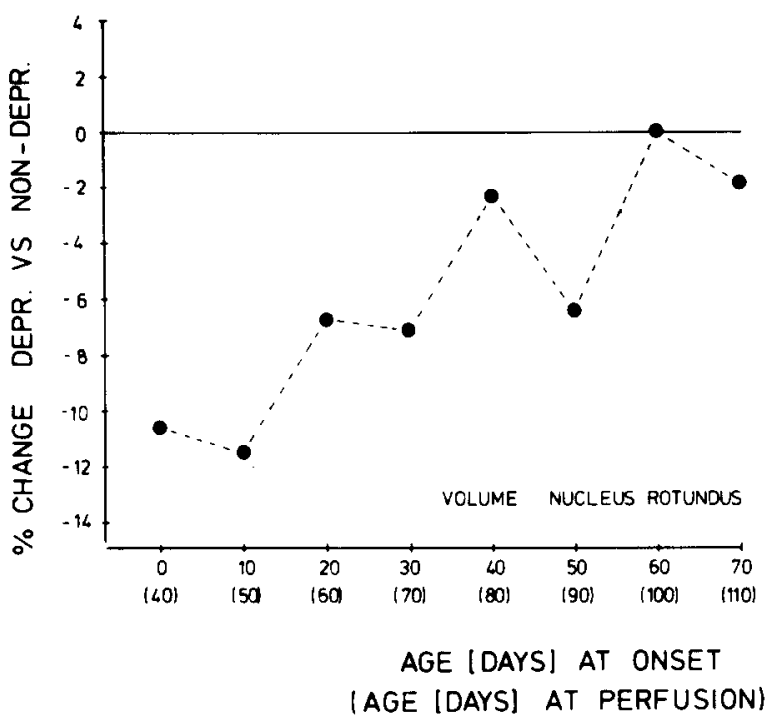

Fig. 3. The effect of 40 days of monocular deprivation at various ages on the rotundal volume of zebra finches. The data show the differences in percent. For further explanation see Fig. 2.

ence between deprived and non-deprived rotundal volume is $11.5 \%\left(0.350 \mathrm{~mm}^{3} \mathrm{vs} 0.418 \mathrm{~mm}^{3}\right)$.

Monocular occlusion in zebra finches deprived from day 20 to 60 results in a $6.8 \%$ difference in rotundus volume of the deprived and undeprived hemisphere. Due to the large individual variations, however, this difference is statistically not significant $\left(0.413 \mathrm{~mm}^{3}\right.$ vs $\left.0.443 \mathrm{~mm}^{3}\right)$.

On the contrary, the interhemispheric asymmetry of $7 \%$ in rotundus volume of birds deprived from day 30 until 70 is highly significant $\left(0.365 \mathrm{~mm}^{3}\right.$ vs 0.393 $\mathrm{mm}^{3}, t=4.3611$, df $\left.=4, P<0.006\right)$.

Deprivation onset at day 40 , however, does not lead to significant changes in the rotundus volume $\left(0.425 \mathrm{~mm}^{3}\right.$ vs $\left.0.435 \mathrm{~mm}^{3}\right)$.

If zebra finches are deprived from day 50 to 90 , the quantitative measurements reveal a non-significant asymmetry of $6.4 \%$. Deprivation at day 60 or 70 does not influence the rotundus volume either (day 60: $0.410 \mathrm{~mm}^{3}$ vs $0.410 \mathrm{~mm}^{3}$; day $70: 0.374 \mathrm{~mm}^{3}$ vs 0.381 $\mathrm{mm}^{3}$ ).

\section{DISCUSSION}

One of the most interesting phenomena in visual deprivation is the fact that the morphological and physiological effects following monocular occlusion in mammals are phase specific. They occur only, if deprivation starts early in ontogeny during the socalled sensitive period. In contrast to a host of literature covering this topic in mammals (for reviews see refs. $4,16,44,55,59$ ), no such information is available about birds so far. This paper is the first to demonstrate the existence of a sensitive period for the effects of monocular deprivation in an altricial bird, the zebra finch.

Two main conclusions can be drawn from our experiments: firstly, a period of normal visual experience prior to monocular deprivation reduces the sensitivity of the nucleus rotundus and the ectostriatum to anatomical changes caused by deprivation. Secondly, the sensitivity curve, derived from the anatomical changes, seems to be double-peaked.

In zebra finches, the susceptibility to the effects of eye closure seems to start directly after hatching. As these birds usually open their eyes at around day 5 , it is most likely that the sensitive period for alterations, caused by a reduced visual input, starts at this age. The sensitivity to external stimuli, measured as the difference between deprived and non-deprived hemisphere, declines then monotonically with delayed deprivation onset. This result of the decreasing effects of monocular deprivation with increasing binocular visual experience is in accordance with anatomical ${ }^{14,58}$ and physiological data from the geniculocortical $^{5,6,33,38,51}$ and extrageniculocortical ${ }^{33}$ pathway of cat and monkey.

However, in contrast to these one-peaked sensitive periods obtained from many physiological studies in mammals, the sensitive period for the effects of monocular deprivation in zebra finches seems to be double-peaked: our data reveal a second peak in susceptibility, if the birds are deprived from day 40 (cell size) or day 50 (volume). Interestingly, such a second rise in sensitivity after the end of the originally presumed critical period was also demonstrated in the lateral geniculate nucleus (LGN) of primates ${ }^{22}$. It must be emphasized that in monkeys neurons in the deprived and non-deprived hemisphere are affected by shrinkage, which does not seem to be the case in zebra finches.

The nature of the morphological changes: shrinkage or hypertrophy?

Due to the lack of data from normally reared birds 


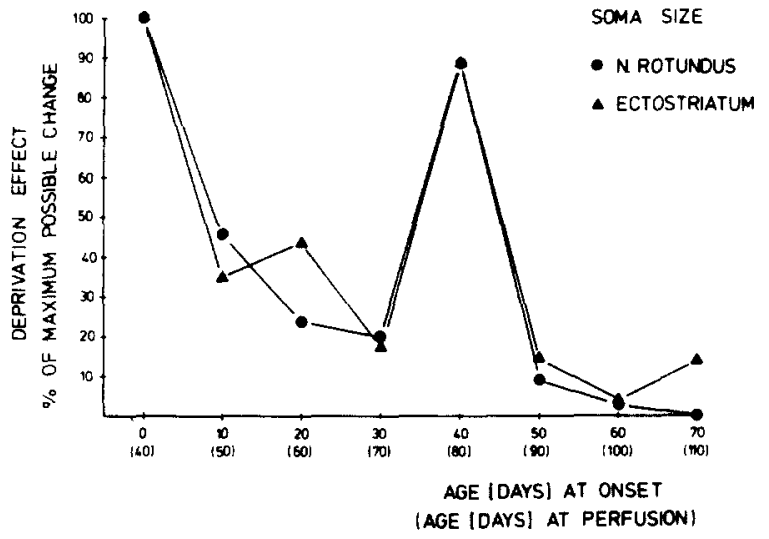

Fig. 4. The sensitive period for the effects of monocular deprivation derived from the cell size data of rotundal and ectostriatal neurons. The absolute difference between the soma size in the deprived and non-deprived hemisphere following neonatal eye closure for 40 days was set $100 \%$ (= maximum possible change). The left-right differences following delayed deprivation refer to this value.

of the same age in this study we have no direct information on the nature of these morphological effects of delayed deprivation onset, which could either result from shrinkage of the deprived neurons or from growth of cells in the non-deprived hemisphere. In spite of the variations among animals, which often make interindividual comparison difficult to interpret, our data concerning cell sizes in the nucleus rotundus $^{26}$ and the ectostriatum ${ }^{27}$ following neonatal lid closure for at least 40 days provide evidence that the deprivation effects are due to a hypertrophy of neurons in the non-deprived hemisphere rather than

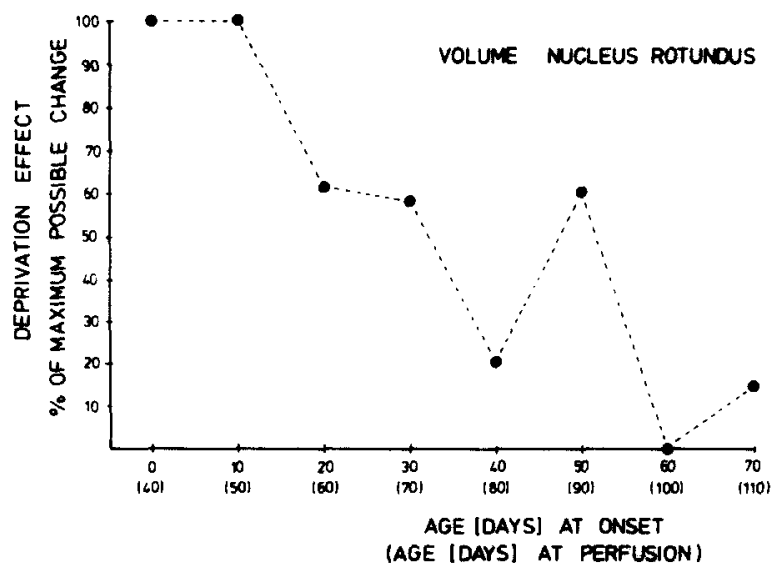

Fig. 5. The sensitive period for the effects of monocular deprivation as revealed from the rotundus volume. For further explanation see Fig. 2. a result of shrinkage of the deprived neurons. This phenomenon was also demonstrated in monocularly deprived monkeys ${ }^{22}$ and cats ${ }^{30}$. However, we do not definitively know whether this also holds true for birds deprived later in life.

One clue comes from normally reared zebra finches. In these birds the size of rotundal as well as ectostriatal neurons declines monotonically from day 20 until adulthood ${ }^{25}$. Comparing the calculated values for animals of the age of day $50,60,70,80$ and 90 , with the deprived birds of this study, at least the second rise in the left-right asymmetry following deprivation from day 40 to 80 is also a result of a hypertrophy, i.e. a growth of neurons on the non-deprived hemisphere and not a shrinkage of the deprived neurons.

The reason for cell size changes is still unclear. Based on a series of experiments Guillery ${ }^{19}$ and Guillery and Stelzner ${ }^{20}$ hypothesized that the changes induced by deprivation reflect the extent of axonal arborization. This idea was recently confirmed by Pearson et al. ${ }^{52}$ and Hendrickson and Deneen ${ }^{23}$. Further research in the zebra finch will address this question.

\section{Early versus late plasticity}

The explanations for the high sensitivity to external stimuli of the nervous system early in ontogeny are all based on the assumption, that during this period the synaptic contacts are still weak and easily modifiable. A series of developmental studies of the nucleus rotundus and the ectostriatum has provided evidence for this assumption. For example, the vast majority of dendritic spines and synapses are formed during the early postnatal period both in zebra finches and in mammals $7,24,28,60$. Additional evidence comes from studies of Le Vay et al..$^{40,41}$ and Shatz and Stryker ${ }^{54}$. They demonstrated that the ocular dominance columns in the visual cortex of cat and monkey develop by a retraction of geniculocortical synapses (segregation), which means that in early ontogeny not only progressive but also regressive processes seem to take place, a phenomenon which has been studied extensively in the visual system of rabbits ${ }^{46}$, cats $^{9.60}$, monkeys ${ }^{7,17.32}$, $\operatorname{man}^{13,34,43}$ and birds $^{24,25}$. These results nourish the idea that the existence of an early sensitive period is perhaps generally linked to the presence of overabundant or re- 
dundant synaptic material ${ }^{46}$ from which only functional connections are selected and stabilized, as Changeux's hypothesis claims ${ }^{8}$. This view is supported by many ontogenetic studies in which a transient overshoot and subsequent reduction of spines or synapses in some way always coincides with the presence of a sensitive period ${ }^{1,5,7,9,24,25,33,46,51,60}$ (the present study, Herrmann and Bischof, submitted).

The interpretation of the second sensitive period has to be based on other arguments. At day 40 , the onset of the deprivation period, the development of the nucleus rotundus and the ectostriatum has reached the adult morphology, yet the reduction process is still in progress. It may be speculated, that the drastic effects result from the elimination of the possibility to functionally verify those contacts which are to be stabilized. Another line of interpretation might be, that the drastic effects of deprivation starting at day 40 are due to late-occurring developmental processes, such as the establishment of new projections which might be activity dependent. Recent electrophysiological results from our lab showing that the physiological patterns of visual areas are probably not complete at day 40 (Engelage and Bischof, in preparation), support this second idea.

In all phases of development there seems to be a delayed response of the total rotundal volume to monocular deprivation in comparison with the cell size (Figs. 4 and 5). The effect of occlusion during the first peak declines more slowly and the second peak occurs with deprivation onset at day 50 instead of day 40. As the volume of a whole brain nucleus might reflect the total neuropil, the parameter 'neuron size', which correlates with the cytoplasmic mass of axon and dendrites, precedes the changes in volume.

In any case these data show that the capacity of the nervous system of birds to react to external stimuli is not restricted to the very early postnatal period. After monocular deprivation later in development other events, such as additional projections estab-

\section{REFERENCES}

1 Apfelbach, R., Imprinting on prey in ferrets (Mustela putorius F. furo L.) and its neural correlates, Behav. Proc., 12 (1986) 363-381.

2 Benowitz, L. and Karten, H.J., Organization of the tectofugal pathway in the pigeon: a retrograde transport study, J. Comp. Neurol., 167 (1976) 503-520. lished later (see above), could well contribute to or interfere with later proliferative or regressive processes.

\section{Correlation with physiological data}

At present the correlations of morphological and physiological events following monocular deprivation are rather speculative. In a second series of experiments we tried to link the morphological effects after delayed occlusion with functional metabolic activity with the aid of the 2-DG method. These data, which will be presented elsewhere in detail, parallel the double-peak, but in contrast to a decreased activity in the areas of the deprived hemisphere following neonatal deprivation, the areas in the deprived hemisphere are more heavily labeled if occlusion starts between day 20 and 60 . Moreover, there seems to be a correlation between the severe anatomical effects of monocular deprivation starting at day 40 and electrophysiological results (Engelage in preparation).

Based on our experiments we cannot definitely decide, whether the sensitive phase for the effects of monocular deprivation is age or experience dependent, a question which was recently raised in a paper of Knudsen and Knudsen ${ }^{39}$ for sound localization in owls. Due to the existence of a second peak following occlusion at day 40 , we favour the idea that the critical period is age dependent. However, experiments with zebra finches binocularly deprived prior to monocular deprivation should help to solve this question definitely.

\section{ACKNOWLEDGEMENTS}

We are grateful to Edda Geissler for preparing the photographs and to Robert Church for correcting the English manuscript. This research was supported by grants from the Minister für Wissenschaft und Forschung des Landes Nordrhein-Westfalen and from the Deutsche Forschungsgemeinschaft (Bi 245/3).

3 Bischof, H.-J., Environmental influences on early development: a comparison between imprinting and cortical plasticity. In P.P.G. Bateson and P.H. Klopfer (Eds.), Perspectives in Ethology Vol. 6, Mechanisms, Plenum, New York, 1985, pp. 169-217.

4 Blakemore, C., Maturation and modification in the developing visual system. In R. Heid, H.W. Leibowitz and H.L. Teuber (Eds.), Perception. Handbook of Sensory Physiolo- 
gy Vol. VIII, Springer, Heidelberg, 1978, pp. 377-426.

5 Blakemore, C., Garey, C.J. and Vital-Durand, F., The physiological effects and their reversal in the monkey's visual cortex, J. Physiol. (Lond.), 283 (1978) 223-262.

6 Blakemore, C. and Van Sluyters, R.C., Reversal of the physiological effects of monocular deprivation in kittens: further evidence for a sensitive period, J. Physiol. (Lond.), 237 (1974) 195-216.

7 Boothe, R.G., Greenough, W.T., Lund, J.S. and Wrege, $\mathrm{K}$., A quantitative investigation of spine and dendrite development of neurons in the visual cortex (area 17) of $\mathrm{Ma}$ caca nemestrina monkeys, J. Comp. Neurol., 186 (1979) 473-490.

8 Changeux, J.P. and Danchin, A., Selective stabilization of developing synapses as a mechanism for the specification of neuronal networks, Nature (Lond.), 264 (1976) 705-712

9 Cragg, B., The development of synapses in the visual system of the cat, J. Comp. Neurol., 160 (1975) 147-166.

10 Cynader, M., Prolonged sensitivity to monocular deprivation in dark-reared cats: effects of age and visual exposure, Dev. Brain Res., 8 (1983) 155-164.

11 Cynader, M., Timney, B.N. and Mitchell, D.E., Period of susceptibility of kitten visual cortex to the effects of monocular deprivation extends beyond six months of age, Brain Research, 191 (1980) 545-550.

12 Daw, N.W. and Wyatt, H.J., Kittens reared in an unidirectinal environment: evidence for a sensitive period, $J$. Physiol. (Lond.), 257 (1976) 155-170.

13 De Courten, C. and Garey, L.J., Morphology of the neurons in the human lateral geniculate nucleus and their normal development. A Golgi study, Exp. Brain Res., 4 (1982) 159-171.

14 Dürsteller, M.R., Garey, C.J. and Movshon, J.A., Reversal of the morphological effects of monocular deprivation in the kitten's lateral geniculate nucleus, J. Physiol. (Lond.), 261 (1976) 189-210.

15 Engelage, J. and Bischof, H.-J., Enucleation enhances ipsilateral flash evoked responses in the ectostriatum of the zebra finch, Exp. Brain Res., in press.

16 Fregnac, Y. and Imbert, M., Development of neuronal selectivity in primary visual cortex of cat, Physiol. Rev., 64 (1984) 325-434.

17 Garey, L.J. and Saini, K.D., Golgi studies of the normal development of neurons in the lateral geniculate nucleus of the monkey, Exp. Brain Res., 44 (1981) 117-128.

18 Garey, L.J. and Vital-Durand, F., Recovery from monocular deprivation in the monkey: reversal of morphological effects of the lateral geniculate nucleus, Proc. R. Soc. Lond. Ser. B, 213 (1981) 425-433.

19 Guillery, R.W., Binocular competition in the control of geniculate cell growth, J. Comp. Neurol., 144 (1972) 117-127.

20 Guillery, R.W. and Stelzner, D.J., The differential effects of unilateral lid closure upon the monocular and binocular segments in the dorsal lateral geniculate nucleus in the cat, J. Comp. Neurol., 139 (1970) 413-422.

21 Harwerth, R.S., Smith, III, E.L., Duncan, G.C., Crawford, M.L.J. and von Noorden, G.K., Multiple sensitive periods in the development of the primate visual system, Science, 232 (1986) 235-238.

22 Headon, M.P., Sloper, J.J., Hirons, R.W. and Powell, T.P.S., Effect of monocular closure at different ages on deprived and undeprived cells in the primate lateral geniculate nucleus, Dev. Brain Res., 18 (1985) 57-78.
23 Hendrickson, A. and Deneen, J.T., Hypertrophy of neurons in the dorsal lateral geniculate nucleus following striate cortex lesions in infant monkeys, Neurosci. Lett., 30 (1982) 217-222.

24 Herrmann, K., Ontogenese und Plastizität des tectofugalen visuellen Systems von Zebrafinken: eine neuroanatomische Studie zum Einfluss von Plastizität, Thesis, University of Bielefeld, F.R.G., 1987.

25 Herrmann, K. and Bischof, H.-J., Delayed development of song control nuclei in the zebra finch is related to behavioral development, J. Comp. Neurol., 245 (1986) 167-175.

26 Herrmann, K. and Bischof, H.-J., Effects of monocular deprivation in the nucleus rotundus of zebra finches: a Nissl and deoxyglucose study, Exp. Brain Res., 64 (1986) $119-126$.

27 Herrmann, K. and Bischof, H.J., Monocular deprivation affects neuron size in the ectostriatum of the zebra finch brain, Brain Research, 379 (1986) 143-146.

28 Herrmann, K. and Bischof, H.-J., The sensitive period for the effects of monocular deprivation in the zebra finch, Soc. Neurosci. Abstr., 13 (1987) 427.1.

29 Hess, E., Imprinting, Van Norstrand Reinhold, New York. 1973.

30 Hickey, T.L., Spear, P.D. and Kratz, K.E., Quantitative studies of cell size in the cat's dorsal lateral geniculate nucleus following visual deprivation, J. Comp. Neurol., 172 (1972) 265-282.

31 Hoffmann, K.-P. and Cynader, M., Functional aspects of plasticity in the visual system of adult cats after early monocular deprivation, Phil. Trans. R. Soc. Lond. Ser. B, 278 (1977) 411-424.

32 Holstein, G.R., Pasik, T., Pasik, P. and Hamori, J., Early postnatal development of the monkey visual system. II. Elimination of retinogeniculate synapses, Dev. Brain Res., 20 (1985) 15-31.

33 Hubel, D.H. and Wiesel, T.N., The period of susceptibility to the physiological effects of unilateral eye closure in kittens, J. Physiol. (Lond.), 206 (1970) 419-436.

34 Huttenlocher, P.R., de Courten, C., Garey, L.J. and Van der Loos, H., Synaptogenesis in human visual cortex - evidence for synapse elimination during normal development, Neurosci. Lett., 33 (1982) 247-252.

35 Immelmann, K., Song development in the zebra finch and other estrildid finches. In R.A. Hinde (Ed.), Bird Vocalization, Cambridge University Press, Cambridge, 1969, pp. $61-74$.

36 Immelmann, K., Über den Einfluss frühkindlicher Erfahrung auf die geschlechtliche Objektfixierung bei Estrildiden, Z. Tierpsychol. 26 (1969) 677-691.

37 Immelmann, K. and Suomi, S., Sensitive phases in development. In K. Immelmann, G.W. Barlow, L. Petrinovich and M. Main (Eds.), Behavioral Development, The Bielefeld Interdisciplinary Project, Cambridge University Press, Cambridge, 1981, pp. 395-431.

38 Jones, K.R., Spear, P.D. and Tong, L., Critical periods for effects of monocular deprivation: differences between striate cortex and extrastriate cortex, J. Neurosci., 4 (1984) 2543-2555.

39 Knudsen, E.I. and Knudsen, P.F., The sensitive period for auditory localization in barn owls is limited by age, not by experience, J. Neurosci., 6 (1986) 1918-1924.

40 Le Vay, S., Stryker, M.P. and Shatz, C.J., Ocular dominance columns and their development in layer IV of the cat's visual cortex, J. Comp. Neurol., 179 (1978) 223-244. 
41 Le Vay, S., Wiesel, T.N. and Hubel, D.H., The development of ocular dominance columns in normal and visually deprived monkeys, J. Comp. Neurol., 191 (1980) $1-51$.

42 Marler, P., A comparative approach to vocal learning: song development in white-crowned sparrows, J. Comp. Physiol. Psychol. Monogr., 71 (1970) 1-25.

43 Michel, A.E. and Garey, L.J., The development of dendritic spines in the human visual cortex, Human Neurobiol., 3 (1984) 223-227.

44 Movshon, J.A. and Van Sluyters, R.C., Visual neural development, Annu. Rev. Psychol., 32 (1981) 477-522.

45 Mower, G.D., Caplan, C.J., Christen, W.G. and Duffy, F.H., Dark rearing prolongs physiological but not anatomical plasticity, J. Comp. Neurol., 235 (1985) 448-466.

46 Murphy, E.H., Critical periods and the development of the rabbit visual cortex. In J. Stone, B. Dreher and D.H. Rappaport (Eds.), Development of Visual Pathways in Mammals, Liss, New York, 1984, pp. 429-462.

47 Niemann, J., Engelage, J. and Bischof, H.-J., Rückkreuzende visuelle Projektionen im tectofugalen System des Zebrafinken (Taeniopygia guttata castanotis). In N. Elsner and O. Creutzfeldt (Eds.), New Frontiers in Brain Research, Proceedings of the 15th Göttingen Neurobiology, Thieme, Stuttgart, 1987, p. 166.

48 Nixdorf, B. and Bischof, H.-J., Posthatching development of synapses in the nucleus rotundus of the zebra finch: a quantitative electron microscopic study, J. Comp. Neurol., 250 (1986) 133-139.

49 Nixdorf, B. and Bischof, H.-J., Ultrastructural effects of monocular deprivation in the neuropil of nucleus rotundus in the zebra finch: a quantitative electron microscopic study, Brain Research, 405 (1987) 326-336.

50 Olsen, C.R. and Freeman, R.D., Monocular deprivation and recovery during the sensitive period in kittens, $\mathrm{J}$. Neu- rophysiol., 41 (1978) 65-74.

51 Olson, C.R. and Freeman, R.D., Profile of the sensitive period for monocular deprivation in kittens, Exp. Brain Res., 39 (1980) 17-21.

52 Pearson, R.C.A., Neal, J.W. and Powell, T.P.S., Hypertrophy of cholinergic neurones of the basal nucleus following damage of the contralateral nucleus, Brain Research, 382 (1986) 149-152.

53 Revzin, A.M. and Karten, H.J., Rostral projection of the optic tectum and the nucleus rotundus in the pigeon, Brain Research, 3 (1966/67) 264-276.

54 Shatz, C.J. and Stryker, M.P., Ocular dominance in layer IV of the cat's visual cortex and the effects of monocular deprivation, J. Physiol. (Lond.), 281 (1978) 267-283.

55 Sherman, S.M. and Spear, P.D., Organization of visual pathways in normal and visually deprived cats, Physiol. Rev., 62 (1982) 738-855.

56 Sherman, S.M. and Wilson, J.R., Behavioral and morphological evidence for binocular competition in the postnatal development of the dog's visual system, J. Comp. Neurol., 161 (1975) 163-196.

57 Singer, W., Tretter, F. and Yinon, U., Evidence for longterm functional plasticity in the visual cortex of adult cats, J. Physiol. (Lond.), 324 (1982) 239-248.

58 Swindale, N.V., Vital-Durand, F. and Blakemore, C., Recovery from monocular deprivation in the monkey. III. Reversal of anatomical effects in the visual cortex, Proc. Roy. Soc. Lond. Ser. B, 213 (1978) 435-450.

59 Wiesel, T.N., Postnatal development of the visual cortex and the influence of environment, Nature (Lond.), 299 (1982) 583-591.

60 Winfield, D.A., The postnatal development of synapses in different laminae of the visual cortex in the normal kitten and kittens with eyelid suture, Dev. Brain Res., 9 (1983) $155-169$. 